DOI: 10.15393/j9.art.2019.6482

УДК 821.161.1.09“18”

Валентина Васильевна Борисова

(Уфа, Российская Федераиия)

borisova@ufacom.ru

Сергей Сергеевич Шаулов

(Уфа, Российская Федераиия)

sschaulov@gmail.com

\title{
Мотив «рокового насдедства» в романе Ф. М. Достоевского «Идиот»: реадьный, мифопоэтический и историко-литературный комментарий
}

Аннотация. Мотив «рокового наследства» в романе Ф. М. Достоевского «Идиот» рассматривается в статье с трех сторон: во-первых, комментируются его реалии, связанные с московским миром семьи Куманиных, многие члены которой стали прототипами героев произведения; вовторых, «куманинский след» выявляется на уровне сюжета. Реальный комментарий дополняется анализом мифопоэтической модели реализации мотива наследства. Его атрибуты - это «узелок» в руках князя Мышкина и «дело» («письмо»), «загадочным» образом связанные. Цепная связь между этими деталями отражает последовательное, в соответствии с кумулятивной логикой разрешения фольклорной загадки, сюжетное развитие мотива "рокового наследства» в романе. Другая характерная особенность его мифопоэтики - символический параллелизм судеб и образов Рогожина и Мышкина. В-третьих, в статье выявляется связь мотива наследства в тексте Достоевского с литературной традицией, прежде всего с творчеством Л. Толстого и Бальзака. Так, пародийная реактуализация раннего очерка французского писателя «Несчастный» в пасквиле Келлера и Лебедева маркирует переход Достоевского к "реализму в высшем смысле», что подтверждается общей динамикой работы над «Идиотом», которая в итоге свелась к синтезу пережитого личного опыта с литературной традицией и культурной памятью. В результате делается вывод о том, что в процессе художественной реализации мотива «рокового наследства» в романе «Идиот» произошла контаминация автобиографического нарратива с соответствующими фольклорно-мифологическими и литературными моделями.

Ключевые слова: Ф. М. Достоевский, «Идиот», Куманины, мотив «рокового наследства», реальный, мифопоэтический, историко-литературный комментарий

(ㄱ В. В. Борисова, С. С. Шаулов, 2019 
Об авторах: Борисова Валентина Васильевна - доктор филологических наук, профессор, заведующая кафедрой русской литературы, Башкирский государственный педагогический университет им. М. Акмуллы (450008, Российская Федерация, г. Уфа, ул. Октябрьской революции, 3/a); Шаулов Сергей Сергеевич - кандидат филологических наук, доцент кафедры русской и зарубежной литературы, Башкирский государственный университет (450076, Российская Федерация, г. Уфа, ул. Заки Валиди, 32)

Дата поступления: 02.02.2019

Дата публикации: 09.09.2019

Для цитирования: Борисова В. В., Шаулов С. С. Мотив «рокового наследства» в романе Ф. М. Достоевского «Идиот»: реальный, мифопоэтический и историко-литературный комментарий // Проблемы исторический поэтики. — 2019. — № 3. - C. 106-128. DOI: 10.15393/j9.art.2019.6482

$\mathrm{M}$ отив «рокового наследства», необратимо и резко меняющего судьбу героев, нашел отражение во многих произведениях Ф. М. Достоевского послекаторжного периода. Особенно важную роль он играет в романе «Идиот». В этом произведении, работа над которым совпала с драматическими перипетиями в «деле о куманинском наследстве», ставшем для автора «несчастным» [Борисова: 32-42], много реалий, связанных с домом Куманиных, богатых родственников со стороны матери писателя. Они требуют специального комментария, о чем в свое время справедливо писал исследователь московского мира Достоевского Г. А. Федоров [Федоров: 19]. Его разыскания, выявляя «московский след князя Мышкина», продолжает сегодня П. Е. Фокин ${ }^{1}$. Благодаря их исследованиям стал очевиден московский контекст творчества Достоевского.

Так, в романе «Идиот» родовое гнездо купцов Куманиных на Ордынке детально описано как дом Рогожина на Гороховой улице в Санкт-Петербурге:

«Подходя к перекрестку Гороховой и Садовой, он сам удивился своему необыкновенному волнению; он и не ожидал, что у него с такою болью будет биться сердце»².

Писатель наделил князя Мышкина собственными ощущениями: этот дом был хорошо знаком ему с детства. Родители часто привозили его вместе с другими детьми в гости к богатой тетушке, в последний раз он посетил его в 1867 г. вместе с женой Анной Григорьевной.

В описании как самого дома, так и его интерьера, много реальных предметных деталей: 
«Дом этот был большой, мрачный, в три этажа, без всякой архитектуры, цвету грязно-зеленого. <...> Подойдя к воротам и взглянув на надпись, князь прочел: “Дом потомственного почетного гражданина Рогожина” $(8,170)$.

Это прямая отсылка к Куманиным, которые в 1830 г. получили от императора потомственное дворянство, став первостатейными купцами. Упоминание Парфена Рогожина о том, что «этот дом еще дедушка строил» $(8,172)$, также связано с фактами жизни трех поколений Куманиных в родовом гнезде. О нем князь говорит Рогожину: «Твой дом имеет физиономию всего вашего семейства и всей вашей рогожинской жизни» $(8,172)$. Примечательно в его описании сочетание в основном темных тонов и красного цвета:

«Лестница была темная, каменная, грубого устройства, а стены ее окрашены красною краской» $(8,170)$.

Тем же колоритом отмечен кабинет Рогожина:

«Это была большая комната, высокая, темноватая, заставленная всякою мебелью <...>. Красный широкий сафьянный диван, очевидно, служил Рогожину постелью» $(8,172)$.

И темная гостиная его матери разгорожена «перегородкой из красного дерева» $(8,185)$.

И, самое главное, в романе есть персонажи, прототипы которых - из куманинского мира. Первым на них указал Г. А. Федоров, хотя обнаруженные им факты нуждаются как в текстологическом уточнении (из-за отсутствия конкретных указаний на документы: например, на архивы князей Вадбольских и Коршей), так и в развернутой литературоведческой интерпретации, прежде всего с учетом их преломления в произведении писателя.

Действительно, ряд имен для своих героев писатель заимствовал из окружения куманинской семьи. Так, управляющим московской конторы Государственного коммерческого банка, директором которой был В. А. Куманин, служил Евграф Гаврилович Рогожин, а его жену звали Настасья Филипповна. Подтверждение этому факту мы находим в письме Достоевского А. Н. Майкову от 31 декабря 1867 г. (12 января 1868 г.): 
«Из четырех героев - два обозначены в душе у меня крепко» $\left(28_{2}, 239\right)$. Речь идет о Настасье Филипповне и Рогожине. В это время писатель уже приступил к работе над окончательной редакцией «Идиота».

По мнению Г. А. Федорова, в образе другого героя романа, Тоцкого, угадывается личность Валентина Алексеевича Куманина (24.04.1793 - 26.11.1863), человека «представительного, барского, с изысканными манерами, шутливой речью и усмешкой в глазах» [Федоров: 303]. Многие факты его биографии также нашли отражение в сюжетной линии романа «Идиот», связанной с Настасьей Филипповной, прототипом которой можно считать Марию Петровну Куманину (урожденную Веденисову, 1834-1886). В. А. Куманин сыграл в ее судьбе «чрезвычайную роль». Свою воспитанницу, юную сироту, Валентин Алексеевич выдал замуж за племянника, Константина Константиновича Куманина, оставив ей по завещанию большое наследство.

Комментируя прямое отражение этого факта в истории Настасьи Филипповны, - которой опекун «воспитание $<\ldots .>$ дал, как графиню содержал, <...> честного мужа <...> приискал» $(8,137)$, и, желая «обеспечить ее участь в будущем», предложил «сумму в семьдесят пять тысяч рублей», - следует отметить, что Тоцкий дополнительно подчеркнул: «...эта сумма всё равно назначена уже ей в его завещании» $(8,41)$. Писатель ввел в текст и признание Настасьи Филипповны в том, что она «принимает теперь капитал, то вовсе не как плату за свой девичий позор, в котором она не виновата, а просто как вознаграждение за исковерканную судьбу» $(8,42)$. Так могла бы сказать и Мария Петровна, которую «ввели в семью чужую», в мрачный фамильный дом. Вспоминаются слова князя: «Засел бы молча один в этом доме с женой, послушною и бессловесною, $<\ldots>$ и только деньги молча и сумрачно наживая» $(8,178)$.

Но Мария Петровна не оказалась «послушною и бессловесною» женой, она попала в «историю», которая огласилась по всей Москве. Имеется в виду «любовный треугольник», образованный из Константина Константиновича Куманина, его жены и князя Сергея Петровича Вадбольского (1822-1899). 
Последний появился в Москве осенью 1857 г. и, познакомившись с младшим Куманиным, стал часто бывать в ордынском доме, видимо, увлекшись Марией Петровной. «Когда это открылось, князю Вадбольскому было отказано от дому» [Федоров: 304], но он продолжал переписываться с Марией Петровной и даже увез ее, поселив в гостинице.

За дело взялись родственники и вернули Марию Петровну в семью. Князь же грозил, «что если она к нему не вернется, то он сделает какое-нибудь преступление или над собою, или над ее мужем», и через братьев вызвал Константина Константиновича на дуэль [Федоров: 303].

Наконец в «историю» вмешался сам генерал-губернатор Москвы, заставивший князя 19 марта 1858 г. дать подписку «не причинять ни малейшего беспокойства куманинской фамилии» ${ }^{3}$ Мария Петровна потребовала развода, но не получила его. Попытка уйти в Никитский монастырь, которым управляла игуменья Агния, в миру княжна Александра Петровна Вадбольская (1785-1858), родственница князя Сергея, также не удалась, поскольку, как установлено нами, 11 июля 1858 г. игуменья скончалась. Так сложилась судьба Марии Петровны Куманиной. «Многое в ее несчастной жизни имеет отношение к образу Настасьи Филипповны...», - отмечает Г. А. Федоров, полагая, что, приехав в Москву в ноябре 1859 г., автор романа «Идиот» не мог не узнать про эту нашумевшую историю, в которую были вовлечены обитатели куманинского дома [Федоров: 308].

Однако мы считаем, что писатель мог быть наслышан о ней еще раньше - в Петербурге от Ап. Григорьева, первая жена которого, Лидия Федоровна Корш, особа экзальтированная и «жорж-сандка», была близка с Марией Петровной. В письме от 16 января 1858 г. своей сестре Софье, которая была замужем за А. К. Куманиным, отцом Константина Константиновича, она пишет: «...не могу и не хочу оставить Марию Петровну (она так жалка)» - и жалуется, что ей самой «далее нельзя оставаться в Москве»: «...на меня смотрят здесь как-то подозрительно с тех пор, как огласилась история с Марией Петровной» ${ }^{4}$ Как раз в это время Ап. Григорьев просит своего друга Е. Н. Эдельсона сопроводить Лидию Федоровну в поезде из 
Москвы в Петербург: «Когда ты сам поедешь, то имей галантерею позаботиться в дороге о моей жене - ибо она тоже собирается ко мне в побывку» ${ }^{5}$. Судя по всему, Л. Ф. Корш было отказано от дома Куманиных после случившегося скандала.

Таким образом, ко времени работы Достоевского над романом история Марии Петровны Куманиной, на наш взгляд, уже вполне могла стать известной писателю из нескольких источников.

Самый же главный прототип из рода Куманиных — тетушка Александра Федоровна. По свидетельству Анны Григорьевны, которую Федор Михайлович в начале апреля 1867 г. привел в московский дом Куманиных на Маросейке, чтобы представить тетушке, «въ лицъ старушки Рогожиной $\Theta<$ <одоръ> М<ихайловичъ> описываетъ свою родную тетку, А<лександру> Ө<еодоровну > Куманину, жившую въ Москвъ, въ подобной

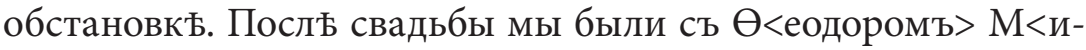
хайловичемъ> въ Москвъ и навъстили его тетку; она приняла насъ чрезвычайно привътливо, но наврядъ-ли знала кто мы такіе» ${ }^{6}$. Страдая тяжелым склерозом, Александра Федоровна к тому времени уже впала в слабоумие и почти ничего не говорила.

Сильное впечатление самого писателя от последней встречи с крестной матерью воспроизведено в романе в мельчайших подробностях:

«Матушка и прежде, вот уже два года, точно как бы не в полном рассудке сидит (больная она), а по смерти родителя и совсем как младенцем стала, без разговору: сидит без ног и только всем, кого увидит, с места кланяется; кажись, не накорми ее, так она и три дня не спохватится» $(8,178)$.

«В углу гостиной, у печки, в креслах, сидела маленькая старушка, еще с виду не то чтоб очень старая, даже с довольно здоровым, приятным и круглым лицом, но уже совершенно седая и (с первого взгляда заключить было можно) впавшая в совершенное детство. Она была в черном шерстяном платье, с черным большим платком на шее, в белом чистом чепце с черными лентами. Ноги ее упирались в скамеечку. <...> старушка, завидев Рогожина и князя, улыбнулась им и несколько раз ласково наклонила в знак удовольствия голову. 
- Матушка, - сказал Рогожин, поцеловав у нее руку, - вот мой большой друг, князь Лев Николаевич Мышкин; мы с ним крестами поменялись; он мне за родного брата в Москве одно время был, много для меня сделал. Благослови его, матушка, как бы ты родного сына благословила. Постой, старушка, вот так, дай я сложу тебе руку...

Но старушка, прежде чем Парфен успел взяться, подняла свою правую руку, сложила пальцы в три перста и три раза набожно перекрестила князя. Затем еще раз ласково и нежно кивнула ему головой.

Когда опять вышли на лестницу, он <Рогожин> прибавил:

- Вот она ничего ведь не понимает, что говорят, и ничего не поняла моих слов, а тебя благословила...» $(8,185)$.

Не ушли без благословения от тетушки и Федор Михайлович с Анной Григорьевной.

По другому свидетельству, принадлежащему Л. Ф. Достоевской, писатель «очень любил свою старшую тетку Куманину, хотя и несколько подтрунивал над ней, что обычно свойственно юным племянникам. Он изобразил ее в "Игроке" в лице старой московской бабуленьки, которая приезжает в Германию, играет в рулетку, проигрывает половину своего состояния и так же поспешно, как приехала, возвращается в Москву. В то время, когда в Германии процветала рулетка, Куманина была слишком стара для путешествий. Но, возможно, она играла в карты в Москве и проигрывала большие суммы. Посылая ее в Германию и заставляя рядом с собой играть в рулетку, Достоевский, может быть, хотел показать, от кого он унаследовал страсть к игре» [Достоевская: 43-44].

Здесь дочерью писателя допущена фактическая ошибка. На самом деле страсть играть в карты на деньги имела бабушка Ольга Яковлевна Нечаева, на которой во втором браке был женат дед писателя Федор Тимофеевич Нечаев. Об этом неоднократно упоминает А. М. Достоевский, описывая свои московские визиты в воспоминаниях: «Посль сытнаго объда, бабушка конечно для своего удовольствія устроила пульку въ преферансъ; не помню кто былъ четвертымъ, но только по записи видно что я проигралъ три рубля (конечно не нарочно) чъмъ еще болъе пріобрьлъ Симпатію бабушки Ольги Яковлевны» ${ }^{7}$. 
И, наконец, «куманинский след» обнаруживается в самом сюжете романа «Идиот»:

«- Верное дело, - объявил наконец Птицын, складывая письмо и передавая его князю. - Вы получаете безо всяких хлопот, по неоспоримому духовному завещанию вашей тетки, чрезвычайно большой капитал» $(8,139)$.

В данном случае несомненно отражение сокровенной мечты самого Федора Михайловича о спасительном наследстве, что видно из его писем 1869 г. к В. И. Веселовскому и брату Андрею $(29,47-48,94-100)$, которые подтверждают автобиографический характер слов Мышкина:

«...получил в Швейцарии письмо из Москвы от одного господина $<\ldots .>$, и он меня уведомляет, что я будто бы могу получить очень большое наследство» $(8,139)$.

Явная перекличка с судьбой А. Ф. Куманиной наблюдается далее по тексту романа:

«Птицын объяснил, обращаясь преимущественно к Ивану Федоровичу, что у князя пять месяцев тому назад умерла тетка <...>, родная и старшая сестра матери князя, дочь московского купца третьей гильдии, Папушина...» (курсив наш. - B. Б., С. Ш.) $(8,139)$.

В упоминании о старшем родном брате Папушина, который «был известный богатый купец», по нашему мнению, также отражаются родственные связи Куманиных.

Но, как в реальной действительности, так и в художественном мире романа, «богатое наследство» оказалось преувеличенным:

«Всё, что говорилось о наследстве, "так сказать о факте наследства”, оказалось верным, но что самое наследство в конце концов оказывается вовсе не так значительным, как об нем сначала распространили. Состояние наполовину запутано; оказались долги, оказались какие-то претенденты, да и князь, несмотря на все руководства, вел себя самым неделовым образом. <... . . явились, например, кредиторы покойного купца, по документам спорным, ничтожным, а иные, пронюхав о князе, так и вовсе без документов, - и что же? Князь почти всех удовлетворил, несмотря на представления друзей о том, что все эти людишки и кредиторишки совершенно без прав...» $(8,153)$. 
В описанной ситуации прямым образом отражено состояние «куманинского дела» после смерти А. П. Иванова, второго душеприказчика, и еще более явственна перекличка с вексельными долгами Федора Михайловича, что отметила

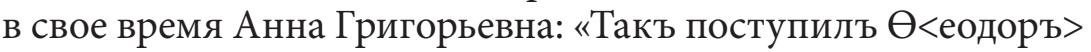
$\mathrm{M}<$ ихайловичъ> когда, послъ смерти своего брата (Михаила Михайловича) рбшилъ удовлетворить всъхъ его кредиторовъ (по журналу “Эпоха" и по табачной фабрикъ), изъ которыхъ нбкоторые не представили никакихъ доказательствъ того, что имъ Мих<аилъ> Мих<айловичъ> остался долженъ» ${ }^{8}$.

Таким образом, данные реального комментария позволяют сделать вывод о большой степени автобиографичности образа и сюжета князя Мышкина, что обусловлено «московским», «куманинским» контекстом, который дополняется в романе мифопоэтическими моделями реализации мотива наследства. Его важнейшие атрибуты в романе «Идиот» - это «узелок» в руках князя Мышкина и «дело», о котором он несколько раз пытается рассказать другим персонажам в первой части произведения.

С начальных страниц подчеркивается не угадываемая окружением князя ассоциативная связь между «узелком» и «наследством», синонимы которого - «состояние» и «достояние»:

«В руках его болтался тощий узелок из старого, полинялого фуляра, заключавший, кажется, всё его дорожное достояние» (курсив наш. - В. Б., С. Ш.) $(8,6)$.

Символический смысл придает «узелку» только проницательный Лебедев: «Узелок ваш все-таки имеет некоторое значение». Он пророчески добавляет, что хотя «в нем не заключается золотых заграничных свертков с наполеондорами и фридрихсдорами, ниже с голландскими арапчиками $\langle\ldots\rangle$, но... если к вашему узелку прибавить в придачу такую будто бы родственницу, как, примерно, генеральша Епанчина, то и узелок примет некоторое иное значение...» (курсив наш. В. Б., С. Ш.) $(8,7)$.

Собственно, Лебедев первым из персонажей романа предлагает свое разрешение загадки «узелка»: князь едет за милостыней к богатой родственнице. Этот сюжетный мотив 
повторяется в тексте трижды: в размышлениях лакея Епанчиных («камердинеру зашло в голову, что тут два дела: или князь так, какой-нибудь потаскун и непременно пришел на бедность просить...»- $(8,18)$; в речи генерала («не больше как жалкий идиот и почти что нищий и принимает подаяние на бедность. Генерал именно бил на эффект...» - $(8,44)$; и даже в речи самого князя: «Давеча ваш слуга, когда я у вас там дожидался, подозревал, что я на бедность пришел к вам просить...» $(8,23)$.

Одновременно подчеркивается особое, символическое значение «узелка». Оно действительно проявляется благодаря неоднократному и настойчивому упоминанию о том, что в руках князя именно «узелок» и едет он в Петербург с «делом». В результате возникает эффект остранения, характерный, по мнению А. П. Квятковского, для фольклорной загадки [Квятковский: 107]. Он усиливает странность и загадочность отмеченных деталей, что становится очевидным в сцене общения князя с камердинером Епанчиных:

«Князю отворил ливрейный слуга, и ему долго нужно было объясняться с этим человеком, с самого начала посмотревшим на него и на его узелок подозрительно. <..>

- Подождите в приемной, а узелок здесь оставьте, - проговорил он, неторопливо и важно усаживаясь в свое кресло и с строгим удивлением посматривая на князя, расположившегося тут же рядом подле него на стуле, с своим узелком в руках» $(8,16)$.

В тексте не раз подчеркивается, что узелок князя не дает слуге покоя и вызывает подозрение, так же как и упоминание о «деле», с которым Мышкин пришел к Епанчиным:

«- Как? Познакомиться? - с удивлением и с утроенною подозрительностью спросил камердинер. - Как же вы сказали сперва, что по делу?

- О, почти не по делу! То есть, если хотите, и есть одно дело, так, только совета спросить <...» $(8,18)$.

В подтексте разговора князя Мышкина с Ганей Иволгиным также обнаруживается загадочная связь «узелка» с «состоянием»: 
- Да со мной поклажи всего один маленький узелок с бельем, и больше ничего; я его в руке обыкновенно несу. <...>

- Два слова-с: имеете вы хотя бы некоторое состояние? <...>

- Помилуйте, я ваш вопрос очень ценю и понимаю. Никакого состояния покамест я не имею и никаких занятий, тоже покамест, а надо бы-с. А деньги теперь у меня были чужие, мне дал Шнейдер, мой профессор, у которого я лечился и учился в Швейцарии, на дорогу, и дал ровно вплоть, так что теперь, например, у меня всего денег несколько копеек осталось. Дело у меня, правда, есть одно, и я нуждаюсь в совете...» (курсив наш. - В. Б., С. Ш.) $(8,23-24)$.

В действительно «загадочной» речи Мышкина «состояние» и «дело» выступают как соотносимые понятия: «состояния» пока нет, но «дело» уже есть. Герой не один раз хочет донести эту мысль до невнимательных слушателей:

«-<...> Что же касается до хлеба, то мне кажется...

Генерал опять перебил и опять стал расспрашивать» $(8,24)$. «- И у вас в России никого, решительно никого? - спросил он.

- Теперь никого, но я надеюсь... притом я получил письмо...

- По крайней мере, - перебил генерал, не расслышав о письме...» (курсив наш. - В. Б., С. Ш.) $(8,25)$.

Мотив «дела», связанного с получением миллионного наследства, «обнажается» в разговоре генерала с Ганей Иволгиным:

«-<...> Не вышло бы анекдота какого-нибудь! — заключил генерал задумчиво.

- Вы миллиона опасаетесь? - осклабился Ганя» (8, 27-28).

И только на вечере у Настасьи Филипповны «узелок» наконец развязывается, а «дело» разъясняется:

«-<..> Но мы, может быть, будем не бедны, а очень богаты, Настасья Филипповна, - продолжал князь тем же робким голосом. - Я, впрочем, не знаю наверно, и жаль, что до сих пор еще узнать ничего не мог в целый день, но я получил в Швейцарии письмо из Москвы от одного господина Салазкина, и он меня уведомляет, что я будто бы могу получить очень большое наследство. Вот это письмо...» $(8,139)$. 
Таким образом, «узелок», «дело» и «письмо» соотносятся как взаимозаменяемые понятия по принципу qui pro quo ${ }^{1)}-$ аналогично метонимической структуре фольклорной загадкииносказания, отмеченной В. П. Аникиным [Аникин: 77].

В таких загадках загадываемый предмет не называется, вместо него дается метонимический эквивалент: «Отгадать помогает качество, свойство предмета загадывания, приписанное замещаюему его предмету. Получается довольно своеобразное построение: предмет загадывания, названный в отгадке, в самой загадке заменен другим предметом или явлением, которому приписаны свойства и качества предмета загадывания» [Митрофанова: 107]. При этом метонимическое соположение предметов требует обоснования, которое выглядит как перевод парадигматической связи образов в синтагматическую, то есть сюжетную. Таким образом, метонимическая загадка содержит в себе потенциально развертываемый нарратив.

Этот механизм «прорастания» сюжета из метонимического сопоставления образов мы можем увидеть и в романе «Идиот». Публичное чтение письма Салазкина - момент раскрытия загадки и разрешения кумулятивно нарастающего внутреннего напряжения сопрягаемых образов. О лежащем в основе наррации метонимическом рядоположении объектов писала в свое время О. М. Фрейденберг: «В повествовательной конструкции иносказание носило еще более древнюю форму 一 ту рядоположную, какую вначале имела и метафора, - не одного образа с двумя смыслами, а двучлена, в котором образ и понятие располагались еще в ряд, отдельно, но были нерасторжимы; мысль выражалась ими обоими зараз» [Фрейденберг: 271]. Собственно, ключевой образный «двучлен» («узелок» - «дело») и есть парадигматическое сопоставление образов в загадке, потенциально способное развернуться в сюжет.

Итак, сюжетному объяснению загадки предшествуют трехкратное повторение высказанной Лебедевым неверной отгадки и многократные указания на особое впечатление, которое производит на окружающих «узелок» князя. Это «оттягивание» ответа на загадку как оттягивание ее сюжетного разрешения

1) qui pro quo - «одно вместо другого» (лат.). 
выполняет те же функции, что и соответствующие элементы фольклорного текста:

- мнемоническую (читатель должен запомнить «узелок» как важную часть образа протагониста);

- экспрессивную (развитие сюжетной темы «узелка» важный элемент постепенного нарастания напряжения в первой части «Идиота» вплоть до скандала, которым заканчиваются именины Настасьи Филипповны).

Подчеркнем, что речь в данном случае идет не о заимствовании образов из конкретных фольклорных текстов, которые могли быть известны Достоевскому, хотя «узелок», несомненно, вбирает в себя и народно-бытовые коннотации, о чем говорила на XLIII Международных чтениях «Достоевский и мировая культура» в ноябре 2018 г. в Санкт-Петербурге О. Ю. Юрьева. Имеется в виду, что в романе «Идиот» воспроизводится переход от загадки-иносказания (метонимического рядоположения образов) к повествованию, объясняющему загадку и устанавливающему синтагматическую связь между этими образами.

Любой образ или ряд образов, предлагаемых читателю для «остраняющей» интерпретации, с необходимостью начинает восприниматься как мифологический, требуя «обнаружения постоянных и вечных принципов, скрытых под обыденной поверхностью» [Мелетинский: 129].

Именно поэтому наличие мифопоэтического уровня смыслов в романе «Идиот» (как и в других романах «великого пятикнижия» Достоевского) воспринимается как аксиома. И споры вокруг романа - это споры о направлениях интерпретации романного мифа, а не о его существовании. В данной связи внимания заслуживает и характерный для романа Достоевского символический параллелизм образов.

Так, явную параллель в судьбах Рогожина и Мышкина отметила И. Ахундова, связав ее с архаическим близнечным мифом [Ахундова: 369]. В общем оксюморонном свете герои представлены как «миллионер в тулупе» $(8,10)$ и «князь с узелком», причем Рогожин, обращаясь к Мышкину, это оксюморонное сходство подчеркивает: 
«-<..> Пять недель назад я вот, как и вы, с одним узелком от родителя во Псков убег, к тетке; да в горячке там и слег, а он без меня и помре» (курсив наш. - В. Б., С. Ш.) $(8,10)$.

Рогожина и Мышкина напрямую связывает «нечто достопримечательное собственно в миллионе и в получении наследства» $(8,10)$, за которым они одновременно едут и бросают его затем к ногам Настасьи Филипповны. Причем объявление об их наследстве вызывает сходный драматический эффект неожиданности в парных сценах:

«- Да... как же это? - удивился до столбняка и чуть не выпучил глаза чиновник, у которого всё лицо тотчас же стало складываться во что-то благоговейное и подобострастное, даже испуганное, - это того самого Семена Парфеновича Рогожина, потомственного почетного гражданина, что с месяц назад тому помре и два с половиной миллиона капиталу оставил?» $(8,9)$. Cp.:

«- Да что такое, что такое? - спохватился генерал, смотря на всех как полоумный, - да неужто наследство?» $(8,139)$.

Князь так же, как и Рогожин после внезапной смерти отца, получает наследство после недавней кончины известного богатого купца Папушина, о чем объявляет Птицын, говоря князю:

«-<..> Может быть, тоже миллиона полтора получите, а пожалуй что и больше» (курсив наш. - В. Б., С. Ш.) $(8,140)$.

И в обеих парных сценах знаковой фигурой выступает Лебедев, который «не утерпел, вышел из своего угла и, согнувшись в три погибели, стал заглядывать в письмо чрез плечо Птицына, с видом человека, опасающегося, что ему сейчас дадут за это колотушку» $(8,139)$.

Как видим, символический параллелизм двух сцен обусловлен ключевым сюжетным мотивом «рокового наследства». Он «технически» сближает судьбы героев в самом начале романа и определяет их связь в восприятии читателя.

Наконец, мотив «рокового наследства», структурообразующий для первой части романа «Идиот», без сомнения, может быть вписан и в богатейший литературный контекст. Так, 
в европейской литературе Нового времени мотив наследства используется для обострения сюжета: наследство либо никак и никем не ожидается, в том числе и главным героем («История Тома Джонса, найденыша» Г. Филдинга), либо его получает самый слабый (Эрнест де Ресто в «Гобсеке» Бальзака), либо самый простодушный (Пестряк в «Наследнике дьявола» Бальзака), либо самый недостойный герой / героиня (куртизанка «Огонёк», «хорошенькая, как купидон», в том же «Гобсеке»). Наследство способно резко и неожиданно поменять ход жизни героя (по сути, это аналог приема «deus ex machina»²), поставить его в неожиданные обстоятельства, резко и выпукло очерчивающие его личность.

Стремлением к этому эффекту объясняется и частое соединение мотива получения наследства с мотивом приезда, перемены места. Точная модель такой сюжетной вариации - это появление в провинции Онегина, «всевышней волею Зевеса, наследника всех своих родных». Примечательно, что, указав на конкретную цель приезда Онегина (получение наследства) и дав в связи с этим первую психологическую характеристику своего героя (размышления Евгения по дороге в имение дяди), Пушкин затем не развивает этот сюжет. Наследство дяди служит только мотивировкой перемещения петербургского денди в русскую провинцию. Далее, когда речь идет о том, почему Евгений не вернулся в Петербург после получения наследства, на первый план опять выходит психологическая логика. Бытовая причина решения героя жить в деревне (управление имением) упоминается только вскользь.

Тот же самый мотив - внезапный приезд наследника, с которого начинается сюжет, - использует Лев Толстой в начале «Войны и мира». Напомним, что «1805 год» был опубликован в первых двух номерах журнала «Русский вестник» за 1865 г., за два года до начала работы Достоевского над «Идиотом». Последний, разумеется, следил за публикациями «конкурентов» и редакционной кухней «Русского вестника». К примеру, в письме Врангелю от 18 февраля 1866 г. он объясняет относительный успех своих переговоров с М. Н. Катковым тем, что

2) «бог из машины» (лат.) - неожиданное разрешение какого-либо конфликта, вариант развязки или постановочного приема. 
«у них из беллетристики на этот год ничего не было: Тургенев не пишет ничего, а с Львом Толстым они поссорились» $\left(28_{2}, 151\right)$.

Сходство мотивов, с которых начинается сюжет обоих романов, дополняется многократно замеченным характерологическим сходством самих протагонистов: «Пьер Безухов, крестящийся свечой, в известном смысле такой же “идиот", как и князь Мышкин, думающий весь вечер о том, чтобы не разбить китайскую вазу» [Померанц: 45].

В обоих произведениях мотив наследства, в конечном счете выведенный авторами из основного действия и оставленный на обочине повествования, успевает резко изменить систему человеческих отношений. Наследство Пьера приводит его к женитьбе на Элен и отдаляет от Наташи, наследство Мышкина формирует систему напряженных связей между героями (Аглая - Мышкин - Настасья Филипповна - Рогожин), которая разрешается в финальной трагедии.

Однако литературная тема наследства ко времени работы Достоевского над романом имела и другие варианты. Совмещаясь с темой денег, она стала средством острейшей социальной критики и сатиры. В романе «Идиот» наследство Мышкина выходит на первый план повествования не только в финале пети-жё у Настасьи Филипповны, но и в знаменитом пасквиле Келлера и Лебедева. В этом фельетоне очевидны несколько тематических и стилевых доминант:

- стремление вписать частный случай в общий контекст русской современности и истории («Странные дела случаются на нашей так называемой святой Руси, в наш век реформ и компанейских инициатив, век национальности и сотен миллионов, вывозимых каждый год за границу, век поощрения промышленности и паралича рабочих рук!» $(8,217)$;

- гротескно-парадоксальное описание характера «идиота» («Шатодефлёрские гувернантки не помогли, и до двадцати лет наш воспитанник не научился даже говорить ни на каком языке, не исключая и русского» $(8,218)$;

- многословие и излишняя красочность слога вкупе со стремлением к афористичности («фортуна, убивающая голодною смертью целые губернии, проливает все свои дары разом на аристократика...»), прямая публицистическая активность 
авторского голоса («крепостные души! понимаете ли вы, господа, такое выражение? Я не понимаю» $(8,218)$.

Этот комплекс свойств достаточно ясно указывает на возможный претекст данного фельетона - наследие Бальзака, стиль которого, воспроизведенный в тексте Келлера и Лебедева в упрощенном виде, тем не менее сохраняет особенности «Эстетики словесного изобилия» [Эпштейн: 29-36].

Тематически ближе всего к пасквилю на Мышкина стоит относительно ранний очерк французского писателя «Несчастный». Его протагонист - богатый наследник, измученный «необходимостью» потратить миллион с лишним франков в год. При этом у графа («ибо наш герой молод и носит графский титул») - «нет пороков, мало воображения и всего одна любовница ${ }^{9}$. Характерно противопоставление причуд графа и нужд общества: «...огонь пожирает от тысячи пятисот до тысячи восьмисот франков (граф каждый вечер сжигает вечернее платье своей любовницы. - В. Б., С. Ш.), которые между нами и в обиду молодому миллионеру, будучи превращены в дрова, отлично согрели бы общественные теплушки» ${ }^{10}$. Есть и указание на мнимое милосердие графа: «Нынче зимой он послал благотворительному обществу шестьдесят тысяч фраков, что доказывает его щедрость. Он дал бы больше, да пришлось бы тогда говорить и приказывать, а от такого труда он хочет себя избавить» ${ }^{11}$.

Обвинения против Мышкина в пасквиле нигилистов стилистически и содержательно недалеки от бальзаковского очерка:

«...швейцарский воспитанник остался непреклонен»;

«...вынимает пятидесятирублевую бумажку и посылает благородному молодому человеку в виде наглого подаяния» $(8,220-221)$.

Следует подчеркнуть, что бальзаковский контекст в «Идиоте» замечен давно (см.: [Biron], [Kliger]). Р. Г. Назиров, в частности, указал на связь финальной сцены с рассказом французского писателя «Неведомый шедевр» [Назиров, 2005: 14-15]. Очерк же «Несчастный», возможно, прочитанный Достоевским еще в юности, мог актуализироваться в его сознании благодаря выпуклой резкости характера героя, обнажающей противоречия социальной жизни, ряду предметных деталей (сжигание вещей любовницы). Достоевский пародирует в своем романе стиль 
Бальзака, гипертрофируя его красочную иронию и превращая фельетон в орудие вымогательства.

Что стоит за этой трансформацией? В юности Достоевский утверждал, что «характеры Бальзака» - «произведения ума вселенной» $\left(28_{1}, 51\right)$. Заметим - именно «характеры» (в фельетоне нигилистов в «Идиоте» используется формула «очерк наших нравов»). Однако позже, как известно, Достоевский постулировал переход от уровня «характеров» в другую сферу:

«Меня зовут психологом: неправда, я лишь реалист в высшем смысле, то есть изображаю все глубины души человеческой» $(27,65)$.

Пародийная реактуализация бальзаковской традиции в романе «Идиот» маркирует переход писателя к новому пониманию стилевых и мировоззренческих оснований собственного творчества. Это пародия не только на стиль, но и на характерное «реалистическое» отношение к жизни.

Этому отвечает и общая динамика работы над романом «Идиот». В ранних записях на первом плане находилась социально-психологическая проблематика («Разорившееся помещичье семейство <...> в Петербурге» и пр. $(9,140))$. Обнаруживаются в них и очевидные автобиографические контексты («Кормит семейство, а считается, что ничего не делает» (9, 141)). Ср. с письмом С. А. Ивановой от 8 (20) марта 1869 г., в котором Достоевский рассказывает об отношении к нему семьи покойного брата:

«...Вы не знаете, до какой степени я уже успел принять от них всякой неприятности. Злоба, клевета, насмешки - всё это на меня. <...> Теперь они кричат, что я их бросил, я, который им всё отдал!» $\left(29_{1}, 27-28\right)$.

И хотя мотив наследства в пору работы над романом продолжал волновать писателя по вполне понятным личным причинам, в конечном счете Достоевский пришел к синтезу пережитого опыта с литературной традицией и культурной памятью. И самое главное - «Христос и Благая Весть преобразили замысел: возникло новое измерение героев и мощное напряжение их отношений, изменилась концепция главного героя» [Захаров: 278]. 
О синтезирующем характере творческого процесса Достоевского писал и Р. Г. Назиров, подчеркивая парадоксальность «сочетания реального прототипа и житейской ситуации с литературным или легендарным образом-символом, с большим идейным содержанием и в то же время с оценочной нагрузкой (Тартюф, Христос, Мария Магдалина, Каин-богоборец). <..> В основании всех крупных характеров Достоевского лежит парадокс - парадоксальное, «нетипичное» сочетание житейски наблюденного, прозаического или даже низменного с литературно-традиционным, возвышенным: выражаясь несколько резче, синтез скандала и символа» [Назиров, 1982: 87].

«Куманинский элемент» в автобиографическом контексте «Идиота» показывает, что трансформация «скандала» в «символ» стала необходима Достоевскому и при обращении к реально-бытовому материалу из собственной жизни. Как справедливо отмечает В. Н. Захаров, «Достоевский задумал один - написал другой роман», хотя «новый роман вызревал в старом» [Захаров: 272, 277].

«Сильные впечатления», «пережитые сердцем автора действительно» $(16,10)$ сопряглись в его воображении с другими творческими импульсами, что обеспечило в итоге реализацию мотива «рокового наследства» в романе «Идиот» как контаминацию автобиографического нарратива с фольклорно-мифологическими и литературными моделями.

\section{Список сокращений}

РО ИРЛИ - Рукописный отдел Института русской литературы (Пушкинского Дома) РАН (С.-Петербург).

ОР РГБ - Отдел рукописей Российской государственной библиотеки (Москва).

РГАДА - Российский государственный архив древних актов (Москва).

\section{Примечания}

* Исследование выполнено при финансовой поддержке Российского фонда фундаментальных исследований (РФФИ), проект “"Дело о куманинском наследстве” в жизни и творчестве Ф. М. Достоевского», № 18-012-90013 Достоевский.

1 Фокин П. Е. Московский след князя Мышкина // Лекторий «Живое общение» [Электронный ресурc]. URL: https://www.youtube.com/ watch?v=Rz672XcEfSA 
2 Достоевский Ф. М. Полн. собр. соч.: в 30 т. Л.: Наука, 1973. Т. 8. С. 170. Далее ссылки на это издание приводятся в тексте статьи с указанием тома, книги (нижний индекс), страницы в круглых скобках.

3 РГАДА. Ф. 1468 (Князья Вадбольские). Оп. 1. Ч. 1.

4 Корш Л. Ф. Письмо к С. Ф. Корш // ОР РГБ. Ф. 465 (Корши). Карт. 40. Ед. хр. 18. Л. 1.

5 Григорьев Аполлон. Письма. Литературные памятники. М.: Наука, 1999. С. 206.

6 Примечания А. Г. Достоевской к сочинениям Ф. М. Достоевского (РО ИРЛИ. Ф. 100. № 29602. Л. 10 об.) / публ. и примеч. Т. В. Панюковой // Неизвестный Достоевский. 2016. № 2. С. 97.

7 Достоевский А. М. Воспоминания // РО ИРЛИ. Ф. 56. № 1. С. 847. (Л. 541).

8 Примечания А. Г. Достоевской к сочинениям Ф. М. Достоевского... С. 94.

9 Бальзак О. де. Собр. соч.: в 24 т. М.: Правда, 1960. Т. 23. Очерки и письмa. C. 5.

10 Там же. С. 6.

11 Там же.

\section{Список литературы}

1. Аникин В. П. Русские народные пословицы, поговорки, загадки и детский фольклор. - М.: Учпедгиз, 1957. - 240 с.

2. Ахундова И. Р. «Воплощение хаоса и небытия» (Парфен Рогожин демон смерти или персонификация судьбы) // Роман Ф. М. Достоевского «Идиот»: современное состояние изучения. - М.: Наследие, 2001. - С. 364-390.

3. Борисова В. В. «Дело о куманинском наследстве» в жизни и творчестве Ф. М. Достоевского // Неизвестный Достоевский. - 2018. - № 1. C. 32-42 [Электронный pecypc]. - URL: http://unknown-dostoevsky. ru/files/redaktor_pdf/1524832332.pdf (13.01.2019). DOI: 10.15393/j10. art.2018.3481

4. Достоевская Л. Ф. Достоевский в изображении своей дочери / пер. с нем. Е. С. Кибардиной; вступ. ст., подгот. текста и примеч. С. В. Белова. - СПб.: Андреев и сыновья, 1992. - 245 с.

5. Захаров В. Н. Имя автора - Достоевский: очерк творчества. - М.: Индрик, 2013. - 465 с.

6. Квятковский А. Поэтический словарь. - М.: Сов. энцикл., 1966. — 376 с.

7. Мелетинский Е. М. Поэтика мифа. - М.: Наука, 2000. - 407 с.

8. Митрофанова В. В. Русские народные загадки. - Л., 1978. - 178 с.

9. Назиров Р. Г. Творческие принципы Достоевского. - Саратов: Изд-во Саратовского университета, 1982. - 160 с.

10. Назиров Р. Г. Диккенс, Бодлер, Достоевский (К истории одного литературного мотива) // Назиров Р. Г. Русская классическая литература: сравнительно-исторический подход. Исследования разных лет: сб. ст. Уфа: РИО БашГУ, 2005. - С. 7-20.

11. Померанц Г. С. Открытость бездне: встречи с Достоевским. - М.: Сов. писатель, 1990. - 384 с. 
12. Федоров Г. А. Московский мир Достоевского. Из истории художественной культуры XX века. - М.: Языки славянской культуры, 2004. - 465 с.

13. Фрейденберг О. М. Миф и литература древности. - М.: Издательская фирма «Восточная литература» РАН, 1998. - 800 с.

14. Эпштейн М. Н. Парадоксы новизны: о литературном развитии XIXХХ веков. - М.: Сов. писатель, 1988. - 416 с.

15. Kliger Ilya. Anamorphic Realism: Veridictory Plots in Balzac, Dostoevsky and Henry James // Comparative Literature. - 2007. - Vol. 59. - No. 4. P. 294-314.

16. Biron V. Balzac et Dostoïevski // Balzac dans L'Empire russe: de la Russie à l'Ukraine / Klimoff A. (ed.). — Paris: Paris-Musées, 1993. - P. 100-108.

Valentina V. Borisova

(Ufa, Russian Federation)

borisova@ufacom.ru

Sergey S. Shaulov

(Ufa, Russian Federation)

sschaulov@gmail.com

\section{The Motif of the "Fateful Inheritance" in "The Idiot" by F. M. Dostoevsky: a Real, Mythopoetic and Historico-Literary Commentary}

Acknowledgments. The reported study was funded by RFBR according to the research project no. 18-012-90013 Dostoevsky.

Abstract. The motif of the "fateful inheritance" in the novel "The Idiot" by F. M. Dostoevsky is discussed in the article from three viewpoints: first, its facts related to the Moscow world of the Kumanin family, many members of which became prototypes of the characters of the novel are commented; second, the "Kumanin's trace" is evidentiated in its plot. The real commentary is accompanied with the analysis of a mythopoetic model of the inheritance motif implementation. Its attributes are the "bundle" in the hands of Knyaz Myshkin (Knyaz is a historical Slavic title, used both as a royal and noble title in different times of history and different ancient Slavic lands) and the "case" ("letter"), which are "mysteriously" interlinked. A chain connection between these details in the novel reflects a consistent plot development of the motif of the fatal inheritance, elaborated in accordance with a cumulative logic of the solution to a folkloric riddle. Another characteristic feature of its mythopoetics is a symbolic parallelism of destinies and characters of Rogozhin and Myshkin. Third, the article reveals the connection between the inheritance motif in Dostoevsky's text and the literary tradition, primarily with the works of L. Tolstoy and Balzac. Thus, the 
parodic reactualization of an early essay "Unhappy" written by the French writer in the libel of Keller and Lebedev marks Dostoevsky's transition to an "eminent realism", that is confirmed by the general dynamics of the work upon the "Idiot", that is finally reduced to the synthesis of personal experience with literary tradition and cultural memory. As a result, the article comes to a conclusion that during the process of an artistic implementation of the fateful inheritance motif in the novel "Idiot" there took place a contamination of the autobiographical narrative with the corresponding folkloric-mythological and literary models.

Keywords: F. M. Dostoevsky, "The Idiot”, Kumanin, the fateful inheritance motif, real, mythopoetic, historic and literary commentary

About the authors: Borisova Valentina V. - Doctor of Philology, Professor, Head of the Russian Literature Department, M. Akmullah Bashkir State Pedagogical University (ul. Oktyabr'skoy Revolyutsii 3a, Ufa, 450008, Russian Federation); Shaulov Sergey S. - PhD in Philology, Associate Professor of the Department of Russian and Foreign Literature, Bashkir State University (ul. Zaki Validi 32, Ufa, 450076, Russian Federation)

Received: February 2, 2019

Date of publication: September 9, 2019

For citation: Borisova V. V., Shaulov S. S. The Motif of the "Fateful Inheritance" in "The Idiot" by F. M. Dostoevsky: a Real, Mythopoetic and Historico-Literary Commentary. In: Problemy istoricheskoy poetiki [The Problems of Historical Poetics], 2019, vol. 17, no. 3, pp. 106-128. DOI: 10.15393/j9.art.2019.6482 (In Russ.)

\section{References}

1. Anikin V. P. Russkie narodnye poslovitsy, pogovorki, zagadki i detskiy fol'klor [Russian Folk Proverbs, Sayings, Riddles and Children's Folklore]. Moscow, Uchpedgiz Publ., 1957. 240 p. (In Russ.)

2. Akhundova I. R. "The Embodiment of Chaos and Inexistence" (Parfen Rogozhin - the Demon of Death or the Personification of the Fortune. In: Roman F. M. Dostoevskogo "Idiot»: sovremennoe sostoyanie izucheniya [F. M. Dostoevsky's Novel "The Idiot": Current State of the Studying]. Moscow, Nasledie Publ., 2001, pp. 364-390. (In Russ.)

3. Borisova V. V. "The Kumanin Heritage Case" in Life and Works of F. M. Dostoevsky. In: Neizvestnyy Dostoevskiy [The Unknown Dostoevsky], 2018, no. 1, pp. 32-42. Available at: http://unknown-dostoevsky.ru/files/redaktor_ pdf/1524832332.pdf (accessed on January 13, 2019). DOI: 10.15393/j10. art.2018.3481 (In Russ.)

4. Dostoevskaya L. F. Dostoevskiy v izobrazhenii svoey docheri [Dostoevsky as Figured by His Daughter L. Dostoevskaya]. St. Petersburg, Andreev i synov'ya Publ., 1992. 245 p. (In Russ.)

5. Zakharov V. N. Imya avtora - Dostoevskiy: ocherk tvorchestva [The Author's Name is Dostoevsky: an Essay on Creative Works]. Moscow, Indrik Publ., 2013. 465 p. (In Russ.) 
6. Kvyatkovskiy A. Poeticheskiy slovar' [A Poetic Dictionary]. Moscow, Sovetskaya entsiklopediya Publ., 1966. 376 p. (In Russ.)

7. Meletinskiy E. M. Poetika mifa [The Poetics of Myth]. Moscow, Nauka Publ., 2000. 407 p. (In Russ.)

8. Mitrofanova V. V. Russkie narodnye zagadki [Russian Folk Riddles]. Leningrad, Nauka Publ., 1978. 178 p. (In Russ.)

9. Nazirov R. G. Tvorcheskie printsipy Dostoevskogo [The Creative Principles of Dostoevsky]. Saratov, Saratov State University Publ., 1982. 160 p. (In Russ.)

10. Nazirov R. G. Dickens, Baudelaire, Dostoevsky (On the History of One Literary Motif). In: Nazirov R. G. Russkaya klassicheskaya literatura: sravnitel'no-istoricheskiy podkhod. Issledovaniya raznykh let: sbornik statey [Nazirov R. G. Russian Classical Literature: a Comparative Historical Approach. Researches of Different Years: Collection of Articles]. Ufa, Printing and publication department of the Bashkir State University Publ., 2005, pp. 7-20. (In Russ.)

11. Pomerants G. S. Otkrytost' bezdne: vstrechi s Dostoevskim [The Openness to the Abyss: Meetings with Dostoevsky]. Moscow, Sovetskiy pisatel' Publ., 1990. 384 p. (In Russ.)

12. Fedorov G. A. Moskovskiy mir Dostoevskogo. Iz istorii khudozhestvennoy kul'tury XX veka [The Moscow World of Dostoevsky. From the History of Art Culture of the 20th Century]. Moscow, Yazyki slavyanskoy kul'tury Publ., 2004. 465 p. (In Russ.)

13. Freydenberg O. M. Mif i literatura drevnosti [The Myth and Literature of the Ancient Times]. Moscow, Vostochnaya literatura of the Russian Academy of Sciences Publ., 1998. 800 p. (In Russ.)

14. Epshteyn M. N. Paradoksy novizny: o literaturnom razvitii XIX-XX vekov [The Paradoxes of Novelty: on the Literary Development of the 19th-20th Centuries]. Moscow, Sovetskiy pisatel' Publ., 1988. 416 p. (In Russ.)

15. Kliger Ilya. Anamorphic Realism: Veridictory Plots in Balzac, Dostoevsky and Henry James. In: Comparative Literature, 2007, vol. 59, no. 4, pp. 294314. (In English)

16. Biron V. Balzac et Dostoïevski. In: Balzac dans L'Empire russe: de la Russie à l'Ukraine [Balzac in the Russian Empire: from Russia to Ukraine]. Paris, Paris-Musées Publ., 1993, pp. 90-108. (In French) 